Jurnal Basicedu Volume 4 Nomor 1 Tahun 2020 Halaman 183-193

JURNAL BASICEDU

Research \& Learning in Elementary Education

https://jbasic.org/index.php/basicedu

\title{
PEMBELAJARAN PKn DENGAN MODEL COOPERATIVE LEARNING TIPE TALKING STICK
}

\author{
Raudatul Fitri ${ }^{1}$, Neviyarni ${ }^{2}$, Ahmad Zikri $^{3}$ \\ ${ }^{1,3}$ Mahasiswa Pendidikan Dasar. FIP Universitas Negeri Padang \\ ${ }^{2}$ Dosen Pendidikan Dasar, FIP Universitas Negeri Padang \\ Email : sfiooc3435@gmail.com ${ }^{1}$, neviyarni.suhaili911@gmail.com ${ }^{2}$, zikria79@yahoo.com ${ }^{3}$
}

\begin{abstract}
Abstrak
Tujuan penelitian ini adalah untuk mendeskripsikan peningkatan hasil belajar siswa padapembelajaran PKn dengan model Cooperative Learning tipe Talking Stick di kelas IV SDN 01 Bandar Buat. Pendekatan yang digunakan adalah kualitatif dan kuantitatif. Subjek penelitian adalah guru dan siswa yang berjumlah 30 orang. Hasil penelitian ini menunjukkan peningkatan pada hasil belajar siswa. Pada siklus 1 diperoleh rata-rata hasil belajar siswa 81 dan pada siklus 2 adalah 89. Jadi, model Cooperative Learning tipe Talking Stick dapat meningkatkan hasil belajar siswa dalam pembelajaran PKn di kelas IV SDN 01 Bandar Buat Kota Padang.

Kata kunci: Hasil Belajar, PKn, Model Cooperative Learning Talking Stick

Abstract

The purpose of this study was to describe the improvement of student learning outcomes in Civics Education with the Cooperative Learning model of Talking Stick type in class IV SDN 01 Bandar Buat. The approach used is qualitative and quantitative. The research subjects were 30 teachers and students. The results of this study showed an increase in student learning outcomes. In cycle 1, the average student learning outcomes were 81 and in cycle 2 was 89. Thus, the Cooperative Learning model of Talking Stick type can improve student learning outcomes in Civics learning in class IV SDN 01 Bandar Buat Padang.
\end{abstract}

Keyword: Learning Outcomes, Civics, Cooperative Learning Talking Stick Model

@ Jurnal Basicedu Prodi PGSD FIP UPTT 2019

$\triangle$ Corresponding author :

Address : Air Tawar Padang

Email : sfiooc3435@gmail.com

ISSN 2580-3735 (Media Cetak)

Phone : 089531307164 
184 Pembelajaran PKn dengan Model Cooperative Learning Tipe Talking Stick - Raudatul Fitri, Neviyarni dan Ahmad Zikri

\section{PENDAHULUAN}

Proses pembelajaran PKn yang dilakukan guru tersebut, menimbulkan beberapa dampak kepada siswa, yaitu: 1) siswa kurang aktif dan tidak konsentrasi dalam mengikuti proses pembelajaran, 2) siswa tidak bisa menemukan pengetahuannya sendiri karena selalu mendapatkan penjelasan dari guru, 3) siswa kurang berinteraksi dan berpartisipasi secara aktif dengan sesama temannya untuk menyelesaikan masalah dalam pembelajaran $\mathrm{PKn}$, dimana siswa hanya mengandalkan teman untuk memecahkan masalah yang telah diberikan guru. Pada saat kegiatan tanya jawab siswa jarang bertanya tentang materi pembelajaran yang telah diberikan guru. Sementara, apabila guru mengajukan pertanyaan seputar materi pembelajaran yang telah disampaikan, sebagian besar siswa tidak mampu menjawab pertanyaan yang diajukan guru.

Berdasarkan kenyataan dan permasalahan yang telah ditemukan dalam pembelajaran PKn di atas, maka diperlukan suatu pendekatan pembelajaran yang sesuai dengan tujuan $\mathrm{PKn}$ untuk meningkatkan hasil belajar siswa dalam pembelajaran PKn dan mengaitkan antara materi yang dipelajari siswa dengan kehidupan nyata siswa.

Untuk mengatasi permasalahan tersebut diperlukan pendekatan pembelajaran yang dapat menjadikan pembelajaran tersebut efektif dan bermakna. Pendekatan adalah suatu cara pembelajaran yang digunakan sebagai pedoman dalam melakukan suatu kegiatan. Wina (2011:127) mengatakan bahwa "Pendekatan dapat diartikan sebagai titik tolak atau sudut pandang kita terhadap proses pembelajaran". Pendekatan pembelajaran yang dapat membuat pembelajaran menjadi bermakna yaitu pendekatan Contextual Teaching and Learning.

Pendekatan Contextual Teaching and Learning atau yang biasa disebut dengan kontekstual adalah pendekatan yang mengaitkan setiap materi atau topik pembelajaran dengan kehidupan nyata. Untuk mengaitkannya bisa dilakukan berbagai cara, selain mengaitkan materi dengan kondisi faktual, juga bisa disiasati dengan pemberian ilustrasi atau contoh, sumber belajar, media, dan lain sebagainya yang terkait atau ada hubungannya dengan pengalaman hidup nyata, sehingga pembelajaran menjadi lebih menarik dan terasa manfaatnya. Nurhadi (dalam Hosnan, 2014:268) mengemukakan bahwa "Pendekatan Contextual Teaching and Learningadalah konsep belajar yang membantu guru mengaitkan antara materi pembelajaran dengan situasi dunia nyata siswa, dan mendorong siswa membuat hubungan antara pengetahuan yang dimilikinya dengan penerapannya dalam kehidupan sehari-hari". Sejalan dengan itu, Johnson (dalam Tukiran, 2011:49) berpendapat bahwa "Contextual Teaching and Learning merupakan proses pendidikan yang bertujuan menolong para siswa melihat makna di dalam materi akademik dalam konteks kehidupan keseharian mereka, yaitu dengan konteks keadaan pribadi, sosial, dan budaya mereka".

Pendekatan Contextual Teaching and Learning mempunyai kelebihan, yakni pembelajaran menjadi lebih bermakna bagi siswa karena pembelajaran berlangsung secara alamiah dan menambah kreatifitas siswa. Sebagaimana Hosnan (2014:279) mengemukakan kelebihan pendekatan Contextual Teaching and Learning yaitu: (1) Pembelajaran menjadi lebih bermakna dan riil. Artinya siswa dituntut untuk dapat menangkap hubungan antara pengalaman belajar di sekolah dengan kehidupan nyata. Pembelajaran lebih produktif dan mampu menumbuhkan penguatan konsep kepada siswa karena metode pembelajaran kontekstual menganut aliran konstruktivisme, di mana seorang 
185 Pembelajaran PKn dengan Model Cooperative Learning Tipe Talking Stick - Raudatul Fitri, Neviyarni dan Ahmad Zikri

siswa dituntut untuk menemukan pengetahuannya sendiri.

Berdasarkan uraian latar belakang di atas peneliti tertarik untuk membahas masalah dalam suatu penelitian tindakan kelas dengan judul "Peningkatan Hasil Belajar Siswa Dalam Pembelajaran PKn Dengan Pendekatan Contextual Teaching and Learning di Kelas IV SDN 09 Bandar Buat Kota Padang".

\section{METODE}

Jenis penelitian ini adalah Penelitian Tindakan Kelas dengan menggunakan pendekatan kualitatif dan kuantitatif. Penelitian ini dilaksanakan di kelas IV SDN 09 Bandar Buat Kota Padang. Subjek dalam penelitian ini adalah guru dan siswa kelas IV, dengan jumlah siswanya 28 orang. Data yang dikumpulkan dalam penelitian ini adalah rencana pelaksanaan pembelajaran pembelajaran (RPP), aspek guru dan aspek siswa dengan pendekatan Contextual Teaching and Learning. Sumber data penelitian ini adalah data tentang perancanaan, pelaksanaan pembelajaran dan hasil belajar siswa dengan pendekatan Contextual Teaching and Learning. Teknik pengumpulan data yang peneliti gunakan dalam penelitian ini adalah observasi dan tes dengan menggunakan instrumen penelitian yang terdiri dari lembar observasi dan lembar tes. Data yang dikumpulkan dianalisis dengan menggunakan analisis data kualitatif dan data kuantitatif. Analisis data kualitatif yang digunakan menurut Miles dan Huberman (dalam Sugiyono 2011:337) "Analisis data dimulai dengan menelaah sejak mulai pengumpulan data sampai seluruh data terkumpul, data tersebut direduksi berdasarkan masalah yang diteliti, diikuti penyajian data dan terakhir penyimpulan atau verifikasi”. Sedangkan model analisis data kuantitatif menggunakan rumus penilaian yang dikemukakan oleh Ngalim (2012:102) dengan rumus sebagai berikut:

$$
\mathrm{NP}=\frac{R}{S M} \quad \mathrm{x} 100 \%
$$

Keterangan:

$\begin{array}{lll}\text { NP } \quad \text { Nilai presentase yang dicari atau } \\ & \text { diharapkan } \\ & \text { R } \quad \text { Skor mentah yang diperoleh siswa } \\ \mathrm{SM} \quad: & \text { Skor maksimum ideal dari tes yang } \\ & \text { bersangkutan } \\ 100 \quad: \text { Bilangan tetap }\end{array}$

\section{HASIL DAN PEMBAHASAN}

Sebelum pelaksanaan pembelajaran, terlebih dahulu peneliti mempersiapkan rencana pembelajaran, LKS, lembar evaluasi, kunci jawaban evaluasi, lembar pengamatan kognitif, lembar pengamatan afektif, lembar pengamatan rencana pelaksanaan pembelajaran, serta lembar pengamatan aspek guru dan aspek siswa.

Kegiatan awal dimulai dengan guru mengucapkan salam, menyiapkan kondisi kelas, meminta siswa untuk berdoa, mengecek kehadiran siswa, melakukan apersepsi dan menyampaikan tujuan pembelajaran.

Kegiatan inti, Langkah pertama kontruktivisme, guru membuka skemata siswa (1) Guru bertanya jawab dengan siswa tentang makanan dimasa lalu dan masa sekarang, (2) Guru bertanya jawab dengan siswa tentang pengertian globalisasi.

Langkah kedua menemukan, guru meminta siswa keluar kelas untuk menemukan contoh globalisasi pada makanan, pakaian dan gaya hidup (1) Guru memberikan penjelasan kepada siswa agar tidak meribut saat keluar kelas. (2) Guru meminta siswa mencatat hal-hal yang temukan, (3) Siswa mencatat contoh globalisasi pada makanan, pakaian dan gaya hidup yang ditemuinya, (4) Guru meminta siswa kembali kedalam kelas dengan tertib, (5) Siswa kembali kedalam kelas.

Langkah ketiga bertanya, guru meminta siswa memberikan pertanyaan kepadanya 
186 Pembelajaran PKn dengan Model Cooperative Learning Tipe Talking Stick - Raudatul Fitri, Neviyarni dan Ahmad Zikri

temannya atas apa yang telah ditemukan, kemudian guru memanggil beberapa siswa menampilkan hasil temuannya (1) Guru meminta siswa mengumpulkan hasil temuannya, (2) Siswa menampilkan hasil temuannya, (3) siswa lain mendengarkan temannya, (4) Siswa bertanya tentang temuan temannya.

Langkah keempat masyarakat belajar, guru membagi siswa kedalam 4 kelompok, masingmasing kelompok terdiri dari 7-8 orang (1) Guru membagi siswa secara heterogen, (2) Guru memberikan penjelasan tentang pentingnya kerja sama dalam kelompok.

Langkah kelima pemodelan, guru memberikan contoh media gambar kepada siswa (1) Guru memajang media gambar mengenai contoh pengaruh globalisasi dari seluruh dunia pada makanan, pakaian dan gaya hidup, (2) Siswa bersama kelompok memperhatikan media gambar yang dipajang oleh guru, (3) Guru meminta siswa bersama kelompok memprediksi media gambar yang dipajang oleh guru, (4) Guru dan siswa bertanya jawab mengenai media gambar yang dipajang oleh guru, (5) Guru menjelaskan tentang contoh-contoh pengaruh globalisasi pada makanan, pakaian dan gaya hidup, (6) Guru membagikan LDK kepada masing-masing kelompok tentang pengaruh globalisasi pada makanan, pakaian, dan gaya hidup, (7) Siswa bersama kelompok membahas LDK yang dibagikan oleh guru, (8) Siswa dibawah pengawasan guru melakukan diskusi, disini guru berperan sebagai fasilitator dan membimbing siswa dalam melakukan diskusi kelompok, (9) Guru meminta masing-masing perwakilan kelompok menampilkan hasil diskusi kelompok, (10) Guru bersama siswa memeriksa jawaban dari kelompok siswa.

Langkah keenam refleksi, guru mencek kembali pemahaman siswa tentang materi yang telah dipelajari (1) Guru bertanya kepada siswa tentang materi yang belum dimengerti siswa, (2)
Siswa memberikan umpan balik tentang pertanyaan guru.

Langkah ketujuh penilaian nyata, guru memberikan soal-soal evaluasi untuk mengetahui sampai dimata pemahaman siswa mengenai materi, (1) Guru memberikan soal pilihan ganda dan essay kepada siswa, (2) Guru menjelskan kepada siswa cara mengerjakan soal-soal tersebut, (3) Guru meminta siswa mengerjakan secara individu, (4) Siswa mengerjakan soal yang diberikan guru dengan cara bekerja secara individu, (5) Siswa mengumpulkan lembaran jawabannya kedepan kelas.

\section{1) Pengamatan Aspek Rencana Pelaksanaan Pembelajaran (RPP)}

Berdasarkan pengamatan yang dilakukan oleh observer, penilaian terhadap siklus I pertemuan 1 pada RPP yang terdiri dari 28 deskriptor, deskriptor sudah terlaksana 24 . Maka didapatkan persentase dari penilaian RPP $85,71 \%$ berada pada kategori baik.

\section{2) Pengamatan pelaksanaan pembelajaran}

a. Aktivitas guru dalam pelaksanaan pembelajaran PKn dengan pendekatan Contextual Teaching and Learning.

Jumlah skor yang diperoleh adalah 26 dari jumlah skor maksimal yaitu 36 dengan persentase 72,2\%. Hasil pengamatan tersebut menunjukkan bahwa tingkat keberhasilan guru dalam pembelajaran dengan pendekatan Contextual Teaching and Learning cukup. Artinya, semua langkah-langkah dalam pembelajaran cukup terlaksana dengan baik.

b. Aktivitas siswa dalam pelaksanaan pembelajaran dengan pendekatan Contextual Teaching and Learning.

Berdasarkan hasil pengamatan yang dilakukan oleh pengamat terhadap 
187 Pembelajaran PKn dengan Model Cooperative Learning Tipe Talking Stick - Raudatul Fitri, Neviyarni dan Ahmad Zikri

aktivitas siswa dalam kegiatan pembelajaran siklus I pertemuan 1, jumlah skor yang diperoleh 20 dari skor maksimal 36. Dengan demikian, persentase skor ratarata aktivitas siswa adalah $55,5 \%$. Hal ini menunjukkan bahwa kriteria keberhasilan aktivitas siswa termasuk dalam kategori kurang

\section{3) Pengamatan hasil belajar siswa}

a. Aspek penilaian kognitif

Keberhasilan siswa dilihat dari hasil evaluasi yang dilakukan pada akhir siklus I pertemuan I tentang perkembangan pengaruh globalisasi pada makanan, pakaian dan gaya hidup. Hasil belajar siswa kelas IV SDN 09 Bandar Buat Kota Padang yang diperoleh siswa dalam pembelajaran pada siklus I pertemuan I, mencapai nilai rata-rata kelas $69,57 \%$. Hal ini menujukkan bahwa kriteria keberhasilan aspek penilaian kognitif termasuk ke dalam kategori cukup.

b. Aspek Penilaian Afektif

Keberhasilan siswa dari aspek afektif dilihat selama proses pembelajaran berlangsung pada siklus I pertemuan 1 . Nilai yang diperoleh siswa pada aspek afektif berdasarkan paparan datadengan skor rata-rata 5,35\%. Dari data tersebut 18 siswa tergolong tuntas dan 10 orang siswa tergolong tidak tuntas dengan rata-rata nilai $66,96 \%$. Dengan demikian, hasil penilaian aspekafektif siswa kelas IV SDN 09 Bandar Buat Kota Padang termasuk ke dalam kategori cukup.

\section{1) Refleksi Rencana Pelaksanaan Pembelajaran (RPP)}

Dari hasil pengamatan yang dilakukan oleh observer pada siklus I pertemuan 1 diketahui bahwa perencanaan pembelajaran PKn dengan pendekatan Contextual Teaching and Learning dalam kategori sangat baik namun masih ada beberapa deskriptor yang belum muncul diantaranya yaitu: (1) pemilihan materi ajar sesuai dengan karakteristik siswa, (2) Pemilihan sumber dan materi pembelajaran sesuai dengan karakteristik siswa, (3) Selanjutnya kejelasan proses pembelajaran, (4) langkah- langkah pembelajaran sesuai dengan alokasi waktu, (5) Kemudian teknik pembelajaran yang tidak muncul yaitu teknik pembelajaran sesuai dengan karakteristik siswa.

2) Refleksi Pelaksanaan Pembelajaran PKn Dengan Pendekatan Contextual Teaching and Learning Dari Aktivitas Guru dan Aktivitas Siswa

a. Refleksi Aktifitas Guru

Pada saat menyiapkan kelas guru kurang menyiapkan kelas dengan baik dan menyampaikan tujuan pembelajaran dengan bahasa yang jelas. Guru tidak memberikan penegasan mengenai jawaban yang diberikan siswa. Guru tidak mengawasi siswa saat keluar kelas. Guru tidak meminta siswa mendengarkan hasil temuan dari temannya, kemudian setelah siswa selesai memberikan tanggapan guru tidak meluruskan tanggapan yang diberikan siswa. Guru tidak meminta siswa mengulang jawaban yang telah diberikan. Guru kurang menghargai hasil kerja siswa. Guru tidak memberikan arahan kepada siswa tentang apa yang akan dikerjakan. Tidak memberikan kesempatan kepada siswa untuk dapat mengungkapkan pengetahuan yang diperoleh. Tidak mengkondisikan siswa saat bertentangan dalam berpendapat. Guru tidak meminta siswa untuk berdo'a. 
188 Pembelajaran PKn dengan Model Cooperative Learning Tipe Talking Stick - Raudatul Fitri, Neviyarni dan Ahmad Zikri

b. Refleksi Aktifitas Siswa

Siswa tidak berdoa dengan baik dan tidak mendengarkan guru dalam menyampaikan tujuan pembelajaran yang akan dipelajari. Siswa tidak mendengarkan penegasan yang diberikan guru. Siswa tidak berkeliling sekolah untuk menemukan contoh pengaruh globalisasi pada makanan, pakaian dan gaya hidup yang dipelajari. Siswa tidak mendengarkan teman mempersentasikan hasil temuan, kemudian siswa tidak mendengarkan guru meluruskan tanggapan yang diberikan guru. Siswa tidak senang menerima teman kelompok yang telah dibagi guru. Siswa tidak memperhatikan media yang dipajang guru dan memprediksi media tersebut, kemudian perwakilan kelompok siswa tidak mempresentasikan hasil diskusi. Siswa tidak mengulang jawaban yang telah diberikan, kemudian siswa tidak mendengarkan apa yang disampiakan guru. Siswa tidak menunggu dengan tenang saat guru membagikan soal, kemudian siswa tidak mendengarkan guru memberikan arahan. Siswa tidak mau menyimpulkan pembelajaran, kemudian siswa tidak berdo'a.

c. Refleksi terhadap Hasil belajar siswa

Pada aspek kognitif dari 28 siswa yang mendapatkan nilai hanya 15 siswa yang mendapat nilai diatas ketuntasan minimum yang telah ditetapkan. Sedangkan 13 orang lainnya mendapatkan nilai di bawah ketuntasan minimum yang telah ditetapkan sekolah yaitu 75. Selanjutnya pada aspek afektif dari 28 siswa yang mendapatkan nilai hanya 18 siswa yang mendapat nilai diatas ketuntasan minimum. Sedangkan
10 orang lainnya mendapatkan nilai di bawah ketuntasan minimum.

\section{Siklus II}

Sebelum pelaksanaan pembelajaran, terlebih dahulu peneliti mempersiapkan rencana pembelajaran, LKS, lembar evaluasi, kunci jawaban evaluasi, lembar pengamatan kognitif, lembar pengamatan afektif, lembar pengamatan rencana pelaksanaan pembelajaran, serta lembar pengamatan aspek guru dan aspek siswa.

Kegiatan awal dimulai dengan guru mengucapkan salam, menyiapkan kondisi kelas, meminta siswa untuk berdoa, mengecek kehadiran siswa, melakukan apersepsi dan menyampaikan tujuan pembelajaran.

Kegiatan inti dimulai dengan langkah pertama kontruktivisme, guru membuka skemata siswa (1) Guru bertanya jawab dengan siswa tentang komunikasi dimasa lalu dan masa sekarang, (2) Guru bertanya jawab dengan siswa tentang pengertian komunikasi.

Langkah kedua menemukan, guru meminta siswa keluar kelas untuk menemukan contoh globalisasi pada komunikasi (1) Guru memberikan penjelasan kepada siswa agar tidak meribut saat keluar kelas. (2) Guru meminta siswa mencatat hal-hal yang temukan, (3) Siswa mencatat contoh globalisasi pada komunikasi yang ditemuinya, (4) Guru meminta siswa kembali kedalam kelas dengan tertib, (5) Siswa kembali kedalam kelas.

Langkah ketiga bertanya, guru meminta siswa memberikan pertanyaan kepadanya temannya atas apa yang telah ditemukan, kemudian guru memanggil beberapa siswa menampilkan hasil temuannya (1) Guru meminta siswa mengumpulkan hasil temuannya, (2) Siswa menampilkan hasil temuannya, (3) siswa lain mendengarkan temannya, (4) Siswa bertanya tentang temuan temannya.

Langkah keempat masyarakat belajar, guru membagi siswa kedalam 4 kelompok, masing- 
189 Pembelajaran PKn dengan Model Cooperative Learning Tipe Talking Stick - Raudatul Fitri, Neviyarni dan Ahmad Zikri

masing kelompok terdiri dari 7-8 orang (1) Guru membagi siswa secara heterogen, (2) Guru memberikan penjelasan tentang pentingnya kerja sama dalam kelompok.

Langkah kelima pemodelan, guru memberikan contoh media gambar kepada siswa (1) Guru memajang media gambar mengenai contoh pengaruh globalisasi dari seluruh dunia pada komunikasi, (2) Siswa bersama kelompok memperhatikan media gambar yang dipajang oleh guru, (3) Guru meminta siswa bersama kelompok memprediksi media gambar yang dipajang oleh guru, (4) Guru dan siswa bertanya jawab mengenai media gambar yang dipajang oleh guru, (5) Guru menjelaskan tentang contoh-contoh pengaruh globalisasi pada komunikasi, (6) Guru membagikan LDK kepada masing-masing kelompok tentang pengaruh globalisasi pada komunikasi, (7) Siswa bersama kelompok membahas LDK yang dibagikan oleh guru, (8) Siswa dibawah pengawasan guru melakukan diskusi, disini guru berperan sebagai fasilitator dan membimbing siswa dalam melakukan diskusi kelompok, (9) Guru meminta masing-masing perwakilan kelompok menampilkan hasil diskusi kelompok, (10) Guru bersama siswa memeriksa jawaban dari kelompok siswa.

Langkah keenam refleksi, guru mencek kembali pemahaman siswa tentang materi yang telah dipelajari (1) Guru bertanya kepada siswa tentang materi yang belum dimengerti siswa, (2) Siswa memberikan umpan balik tentang pertanyaan guru.

Langkah ketujuh penilaian nyata, guru memberikan soal-soal evaluasi untuk mengetahui sampai dimata pemahaman siswa mengenai materi, (1) Guru memberikan soal pilihan ganda dan essay kepada siswa, (2) Guru menjelskan kepada siswa cara mengerjakan soal-soal tersebut, (3) Guru meminta siswa mengerjakan secara individu, (4) Siswa mengerjakan soal yang diberikan guru dengan cara bekerja secara individu, (5) Siswa mengumpulkan lembaran jawabannya kedepan kelas.

\section{Pengamatan}

1) Pengamatan Rencana Pelaksanaan Pembelajaran (RPP)

Penilaian terhadap RPP yang terdiri dari 28 deskriptor sudah terlaksana yaitu 26 . Maka didapatkan persentase dari penilaian RPP pada pertemuan siklus II adalah 92,85 yang berada pada kategori sangat baik. Komponen RPP dapat dikatakan sudah sesuai dengan yang diharapkan.

2) Pengamatan Pelaksanaan Pembelajaran

a. Aktivitas guru dalam pelaksanaan pembelajaran $\mathrm{PKn}$ dengan pendekatan Contextual Teaching and Learning.

Jumlah skor yang diperoleh adalah 34 dari jumlah skor maksimal yaitu 36 dengan persentase $94,5 \%$. Hasil pengamatan tersebut menunjukkan bahwa tingkat keberhasilan guru dalam pembelajaran dengan pendekatan Contextual Teaching and Learning sangat baik. Artinya, semua langkahlangkah dalam pembelajaran sudah terlaksana dengan sangat baik.

b. Aktivitas siswa dalam pelaksanaan pembelajaran $\mathrm{PKn}$ dengan pendekatan Contextual Teaching and Learning.

Berdasarkan hasil pengamatan yang dilakukan oleh pengamat terhadap aktivitas siswa dalam kegiatan pembelajaran siklus II, jumlah skor yang diperoleh 32 dari skor maksimal 36 . Dengan demikian, persentase skor ratarata aktivitas siswa adalah $88,9 \%$. Hasil pengamatan tersebut menunjukkan bahwa tingkat keberhasilan siswa dalam pembelajaran dengan pendekatan Contextual Teaching and Learning sudah 
190 Pembelajaran PKn dengan Model Cooperative Learning Tipe Talking Stick - Raudatul Fitri, Neviyarni dan Ahmad Zikri

sangat baik. Artinya, semua langkahlangkah dalam pembelajaran sudah terlaksana dengan sangat baik.

3) Penilaian hasil belajar

\section{a. Aspek Penilaian Kognitif}

Keberhasilan siswa dilihat dari hasil evaluasi yang dilakukan pada akhir siklus II. Hasil belajar siswa kelas IV SDN 09 Bandar Buat Kota Padang yang diperoleh siswa dalam pembelajaran pada siklus II, mencapai nilai rata-rata kelas $86,33 \%$. Berdasarkan hasil pengamatan tersebut, masih ada siswa yang mendapatkan nilai di bawah KKM yang telah ditentukan yaitu 2 orang siswa dan 26 orang siswa yang mendapat nilai diatas kriteria ketuntasan minimum (KKM) dari 28 orang siswa. Dengan demikian, hasil penilaian aspek kognitif siswa kelas IV SDN 09 Bandar Buat Kota Padang termasuk ke dalam kategori sangat baik. Maka dapat diambil kesimpulan penelitian tindakan kelas dengan pendekatan Contextual Teaching and Learning sudah berhasil.

\section{b. Aspek Penilaian Afektif}

Berdasarkan lembar pengamatan aspek afektif siklus II, penilaian aspek afektif siswa diperoleh gambaran bahwa 28 orang siswa berada pada kriteria ketuntasan minimum (KKM) dengan kualifikasi sangat baik dengan nilai ratarata yang diperoleh $97,67 \%$. Dengan demikian, hasil penilaian aspek afektif siswa kelas IV SDN 09 Bandar Buat KotaPadangdalam pembelajaran PKn dengan pendekatan Contextual Teaching and Learning termasuk ke dalam kategori sangat baik. Maka dapat diambil kesimpulan penelitian tindakan kelas dengan pendekatan Contextual Teaching and Learning sudah berhasil.

\section{Refleksi Siklus II}

1) Refleksi Rencana Pelaksanaan Pembelajaran (RPP)

Refleksi dari perencanaan siklus II dilihat dari hasil paparan siklus II diketahui bahwa perencanaan pembelajaran sudah terlaksana dengan sangat baik, walaupun masih ada dalam alokasi waktu yang tidak sesuai, namun langkah pembelajaran telah dilaksanakan dengan sangat baik. Artinya RPP pada siklus II telah berhasil.

2) Refleksi aktivitas guru dan siswa

Pelaksanaan pembelajaran dengan pendekatan Contextual Teaching and Learning telah berhasil dilaksanakan sesuai dengan waktu yang direncanakan. Pelaksanaan pembelajaran jika dilihat dari aspek guru dan aspek siswa sudah terlaksana dengan kategori sangat baik.

\section{3) Refleksi Hasil Belajar Siswa}

Dari hasil penilaian pelaksanaan pembelajaran dengan pendekatan Contextual Teaching and Learning yang telah dilaksanakan, dapat dilihat bahwa hasil belajar siswa meningkat. Untuk aspek kognitif meningkat menjadi $86,33 \%$ dan aspek afektif 97,67\%. Dengan demikian, dapat disimpulkan pembelajaran pada siklus II ini telah berjalan sesuai dengan yang direncanakan. Hasil tes siklus II menunjukkan bahwa tingkat ketuntasan untuk kelas telah sesuai dengan apa yang diharapkan. Maka penelitian ini sudah dapat dikatakan berhasil.

Berdasarkan hasil observasi dan diskusi peneliti dengan guru kelas IV, penyebab belum terlaksananya pendekatan Contextual Teaching and Learning siklus I ini adalah siswa kurang mendengarkan apa yang disampaikan guru karena saat proses pembelajaran siswa banyak yang meribut, kemudian saat temannya menampilkan 
191 Pembelajaran PKn dengan Model Cooperative Learning Tipe Talking Stick - Raudatul Fitri, Neviyarni dan Ahmad Zikri

temuan kedepan kelas siswa kurang mendengarkan apa yang disampaikan teman, sehingga saat siswa diminta menanggapi penampilan teman banyak siswa yang diam. Selain itu hal ini juga disebabkan kurangya pengelolaan kelas yang dilakukan oleh peneliti, sehingga peneliti kesulitan mengontrol siswa.

Berdasarkan hasil pengamatan yang diperoleh pada siklus I maka direncanakan untuk melakukan siklus II dengan tujuan agar siswa lebih aktif dan tertarik untuk belajar. Guru seharusnya dapat mengaktifkan semua siswa tanpa kecuali agar potensi yang ada pada siswa dapat tergali dan berkembang. Guru harus dapat memberikan motivasi kepada siswa dalam pembelajaran. Sehingga rencana pelaksanaan pembelajaran (RPP) yang telah dibuat sesuai dengan pelaksanaan pembelajaran yang dilakukan

Berdasarkan diskusi peneliti dengan observer, pelaksanaan pembelajaran pada siklus I masih memiliki kekurangan-kekurangan yang perlu diperbaiki yaitu:

Pelaksanaan pembelajaran belum sesuai dengan yang telah direncanakan. Selama pelaksanaan pembelajaran PKn dengan menggunakan pendekatan Contextual Teaching and Learning ditemukan hal-hal sebagai berikut: (1) pada saat membentuk kelompok, walapun peneliti telah berdisikusi dengan guru kelas dalam membagi kelompok secara heterogen siswa masih banyak yang meribut dan memilih-milih teman, (2) pada saat berdiskusi dalam kelompok siswa masih meribut, tidak mau bekerjasama dengan teman di kelompoknya, (3) siswa kurang berani dalam mengemukakan pendapatnya baik dalam memberikan pertanyaan dalam proses pembelajaran, (4) siswa kurang termotivasi karena guru kurang memotivasi dan memberikan penguatan kepada siswa, (5) dalam kegiatan penutup guru hendaknya memberi catatan kesimpulan dan diminta siswa mencatat di dalam buku tulisnya sebagai bahan siswa untuk belajar di rumah.

Berdasarkan hasil pelaksanaan pembelajaran yang telah dilakukan maka perlu dilakukan perbaikan, untuk itu peneliti melakukan siklus II agar pelaksanaan pembelajaran PKn dengan pendekatan Contextual Teaching and Learning yang diharapkan ini dapat terlaksana dengan sangat baik.

\section{Siklus II}

Berdasarkan analisis data yang dilakukan observer pada lembaran pengamatan RPP diketahui bahwa perolehan skor pada siklus II adalah 26 dengan skor maksimal 28 dengan persentase $92,85 \%$ dengan kriteria sangat baik. Dimana pengorganisasian materi ajar tidak sesuai dengan materi ajar, kemudian pemilihan sumber/materi pesmbelajaran tidak sesuai dengan karakteristik siswa. Berdasarkan pemaparan data yang disajikan di atas, dapat disimpulkan bahwa perencanaan pembelajaran PKn dengan pendekatan Contextual Teaching and Learning di SDN 09 Bandar Buat Kota Padang telah terlaksana dengan kriteria sangat baik pada siklus II.

Pelaksanaan pembelajaran pada siklus II sesuai dengan apa yang telah direncanakan. Berdasarkan diskusi peneliti dengan observer, selama pelaksanaan pembelajaran ditemukan beberapa hal sebagai berikut: (1) penyajian materi dengan pendekatan Contextual Teaching and Learning sudah sesuai dengan perencanaan awal, (2) pada saat membentuk kelompok, siswa tidak lagi memilih-milih teman, (3) siswa sudah tidak ribut saat melakukan diskusi kelompok, karena guru membimbing siswa agar serius berdiskusi, (4) siswa sudah berani mengemukakan pendapatnya, dan mengelola ide-ide dan pemikirannya sehingga tidak mengandalkan temannya yang pandai lagi, (5) siswa sudah termotivasi dalam belajar sehingga siswa semangat dalam belajar, (6) siswa telah 
192 Pembelajaran PKn dengan Model Cooperative Learning Tipe Talking Stick - Raudatul Fitri, Neviyarni dan Ahmad Zikri

mencatat materi yang diberi guru kedalam buku catatan untuk dipelajari selanjutnya dirumah.

Berdasarkan analisis data pengamatan aktivitas guru dan siswa. Pada siklus II pengamatan aktifitas guru diperoleh skor 34 dari skor maksimal 36 dengan persentase $94,5 \%$ dan kualifikasi sangat baik. Pada aktivitas siswa diperolehan skor 32 dari skor maksimal 36 dengan persentase $88,9 \%$ dengan kualifikasi sangat baik.

\section{SIMPULAN}

Dari paparan data, hasil penelitian, dan pembahasan, simpulan yang dapat diambil dari penelitian ini adalah sebagai berikut: Perencanaan pembelajaran dituangkan dalam bentuk RPP. RPP dibuat sesuai dengan langkah-langkah Contextual Teaching and Learning yaitu: kontruktivisme, menemukan, bertanya, masyarakat belajar, pemodelan, refleksi dan penilaian nyata.

Berdasarkan kesimpulan yang telah diperoleh dalam penelitian ini diajukan beberapa saran untuk dipertimbangkan, yaitu diharapkan guru hendaknya dapat membuat rencana pelaksanaan pembelajaran sesuai dengan ketentuan-ketentuan dalam kurikulum dengan pendekatan Cotextual Teaching and Learning dalam pembelajaran $\mathrm{PKn}$, agar pembelajaran berlangsung efektif dan efisien, dan dapat melaksanakan pembelajaran PKn dengan pendekatan Contextual Teaching and Learning. Guru juga sebaiknya melaksanakan pembelajaran sesuai dengan RPP yang telah disusun sehingga pembelajaran diharapkan tercapai dengan baik.

\section{DAFTAR PUSTAKA}

Agus Suprijono. 2012. Cooperative Learning. Teori dan Aplikasi PAIKEM. Yogyakarta: Pustaka Belajar.

Ahmad Susanto. 2013. Teori belajar dan pembelajaran disekolah dasar. Jakarta : Kencana.

Akmal. 2014. Pendidikan kewarganegaraan dalam perspektif ketahanan nasional. Padang : Bung
Hatta University Press.

Aris Shoimin. 2014. 68 Model Pembelajaran Inovatif dalam Kurikulum 2013. Yogyakarta: Ar-Ruzz Media.

Beni Ahmad Saebani. 2008. Metode Penelitian. Bandung: Pustaka Setia.

Basrowi \& Suwandi. 2008. Memahami penelitian kualitatif. Jakarta : Rineka cipta

Departemen Pendidikan Nasional. 2006. KTSP. Jakarta: Depdiknas.

Hamzah B Uno, dkk. 2011. Menjadi Peneliti PTK yang Profesional. Jakarta: Bumi Aksara.

Igak Wardhani dan Kuswaya Wihardit. 2011. Penelitian Tindakan Kelas. Jakarta: Universitas Terbuka.

Imas Kurnaisih \& Berlin Sani. 2015. Ragam Pengembangan Model Pembelajaran. Jakarta: Kata Pena.

Istarani. 2012. 58 Model Pembelajaran Inovatif. Medan: Media Persada.

Kaelan \& Ahmad. 2007. Pendidikan Kewarganegaraan. Yogyakarta : Paradigma.

Kimberly Fujioka. 1998. "The Talking Stick: An American Indian Tradition in the ESL Classroom." The Internet TESL Journal (Vol. IV, No. 9) Hlm 2.

Kunandar. 2008. Langkah mudah penelitian tindakan kelas sebagai pengembangan profesi guru. Jakarta : Rajawali Pers.

Nana sudjana. 2009. Penilaian hasil proses belajar mengajar. Bandung: PT. Remaja rosdakarya.

Ngalim purwanto. 2004. Prinsip-prinsip dan teknik evaluasi pembelajaran. Bandung : PT. Remaja Rosdakarya.

Rusman. 2012. Model-model pembelajaran. Jakarta: Rajawali pers.

Slavin, Robert E. 2005. Cooperative Learning. Bandung: Nusa Media.

Trianto. 2013. Model-Model Pembelajaran Inovatif Berorientasi Kontruktivis. Jakarta: Prestasi Pustaka.

Tukiran taniredja. 2014. Model-model pembelajaran inovatif dan efektif. Bandung: alfabeta.

Wijaya Kusumah dan Dedi Dwitagama. 2011. Mengenal Penelitian Tindakan Kelas. Jakarta: PT Indeks. 
193 Pembelajaran PKn dengan Model Cooperative Learning Tipe Talking Stick - Raudatul Fitri, Neviyarni dan Ahmad Zikri

Zainal Aqib. 2013. Model-Model Pembelajaran Kontekstual (Inovatif). Bandung: Penerbit Yrama Widya. 